\title{
Unifocal Lesion
}

National Cancer Institute

\section{Source}

National Cancer Institute. Unifocal Lesion. NCI Thesaurus. Code C48616.

A lesion arising from or having a single location. 